\title{
Is Bacterial Colonization in Ureteral Double-J Stents Significant and Is It Predictable?
}

\author{
Üreteral Double J Stentlerde Bakteri Kolonizasyonu Anlamlı mıdır ve Idrar Testleri ile Tahmin \\ Edilebilir mi?
}

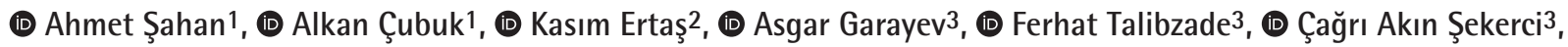 \\ iD Tuncay Toprak ${ }^{3}$, iD Yılören Tanıdır 3 \\ ${ }^{1}$ Kartal Dr. Lütfi Kırdar Training and Research Hospital, Clinic of Urology, Istanbul, Turkiye \\ 2 Van Yüzüncü Yıl University Faculty of Medicine, Department of Urology, Van, Turkiye \\ 3Marmara University Faculty of Medicine, Department of Urology, Istanbul, Turkiye
}

What's known on the subject? and What does the study add?

Stent-related infections are rare and mostly asymptomatic, although it may lead to severe pyelonephritis. Ureteral stents also cause stentrelated symptoms that mimic urinary tract infections. Most of the urologists tend to remove ureteral stents after obtaining sterile urine or with antibiotic suppression however the determination of bacterial colonization with urinalysis and urine culture is insufficient. The present study demonstrates urinalysis and urine culture are not efficient tests for predicting catheter culture results. Ampicillin-tetracycline treatment should be started empirically in patients with postoperative symptomatic infection findings and, finally, UDJSs should not be kept in longer.

\section{Abstract}

Objective: Since microscopic hematuria and pyuria can be observed in patients with a ureteral double-J (DJ) stent in place, urinalysis findings are not considered significant in terms of predicting stent-related infections. This study evaluates the presence of bacterial colonization and the value/ effectiveness of urine tests in predicting the results of DJ stent cultures.

Materials and Methods: In the present prospective study, we analyzed data from patients who were treated with a DJ stent placement following endourological surgery due to ureteral stones. DJ stents were removed only after the urine cultures appeared sterile or after a period of empiric antibiotic use. The relationship between urinalysis results and stent cultures was assessed.

Results: A total of 65 patients (mean age, $42.6 \pm 13.5$ years; 16 females and 43 males) were evaluated. Bacterial colonization was detected in 12 (18\%) DJ stent cultures with Enterococcus faecalis $(\mathrm{n}=4)$, extended-spectrum beta-lactamase producer $(\mathrm{ESBL}(+)$ Escherichia coli $(\mathrm{n}=4)$, Corynebacterium urealyticum $(n=2)$, candida $(n=1)$ and methicillin-resistant Staphylococcus aureus $(n=1)$ growth being reported. The antibiogram results of the patients that showed colonization in their cultures demonstrated penicillin $(n=4)$, ampicillin $(n=4)$, tetracycline $(n=3)$, imipenem $(n=2)$, and linezolid $(n=1)$ sensitivity. The rate of leukocyte esterase- and nitrite-positive patients, of those having significant number of leukocytes, and urine culturepositive patients in the groups with and without positive urine culture was 58.5\%, 32\%, 49\%, and 7.5\% vs 50\%, 16.6\%, 50\%, and 8.5\%, respectively. There were no statistically significant differences between the groups ( $p=>0.05)$. None of the study patients applied to our hospital with active infection following DJ stent removal.

Conclusion: Urinalysis is insufficient in predicting catheter culture results. Based on the results of this study, we assume that stent culture for removed DJ stents is not a necessity; empirical antibiotic therapy with ampicillin-tetracycline should be started in patients with postoperative infection.

Keywords: Double J stent, Colonization, Urinalysis, Stent culture

Öz

Amaç: Üreteral Double-J (DJ) stent takılan hastalarda mikroskobik hematüri ve piyüri sıklıkla eşlik ettiğinden, idrar analizleri enfeksiyonları öngörme açısından anlamlı sayılmazlar. Bu çalışma, üreteral DJ stent kültür sonuçlarını öngörmede idrar testlerinin değeri/ etkinliği değerlendirmektedir.

Correspondence: Ahmet Sahan MD, Kartal Dr. Lutfi Kırdar Training and Research Hospital, Clinic of Urology, İstanbul, Turkiye E-mail: xdr.ahmetsahan@gmail.com ORCID-ID: orcid.org/0000-0001-8079-5875

Received: $16.09 .2019 \quad$ Accepted: 30.12.2019

Cite this article as: Sahan A, Cubuk A, Ertaş K, Garayev A, Talibzade F, Sekerci ÇA, Toprak T, Tanıdır Y. Is Bacterial Colonization in Ureteral Double-J Stents Significant and Is It Predictable? J Urol Surg 2020;7(2):120-124.

๑Copyright 2020 by the Association of Urological Surgery / Journal of Urological Surgery published by Galenos Publishing House. 
Gereç ve Yöntem: Endoskopik üreter taşı tedavisi sonrası üreteral DJ stent takılan hastaların verileri prospektif olarak analiz edildi. İdrar tahlilinde lökosit esteraz pozitifliği, nitrit pozitifliği, anlamlı lökosit varlığı ve idrar kültüründe üreme ile üreteral DJ stent kültüründe üreme arasındaki ilişki değerlendirildi.

Bulgular: Ortalama yaşı 42£68 yıl olan 16 kadın ve 49 erkek toplam 65 hasta çalışmaya dahil edildi. Üreteral DJ stent kültürlerinin 12'sinde (\%18) bakteri kolonizasyonu tespit edildi. Üreteral DJ stent kültürlerinde Enterokok faecalis $(n=4)$, Escherichia coli $(n=4)$, Corynebacterium urealyticum $(n=2)$, kandida $(n=1)$ ve metisilin rezistan staphylococcus aureus $(n=1)$ üremesi raporlandı. Üreteral DJ stent kültür antibiyogramlarında penisilin $(n=4)$, ampisilin $(n=4)$, tetrasiklin $(n=3)$, imipenem $(n=2)$, ve linezolid $(n=1)$ duyarlılğı rapor edildi. Lökosit esteraz pozitifliği, nitrit pozitifliği, anlamlı lökositüri ve idrar kültüründe üreme oranları Üreteral DJ stent kültüründe üreme olan ve olmayan gruplar için sırasıyla \%58,5 vs. \%50, \%32 vs. $\% 16,6, \% 49$ vs. $\% 50$ ve $\% 7,5$ vs. $\% 8,5$ hesaplandı ve gruplar arasında anlamlı farklılık izlenmedi $(p>0,05)$. Üreteral DJ stent çıkarılmasından sonra aktif enfeksiyon ile başvuru izlenmedi.

Sonuç: Steril idrar kültürü ve idrar tahlili parametreleri üreteral DJ stent kültür sonuçlarını öngörmede yetersizdir. Bulgularımıza göre çıkarılan üreteral DJ stentleri mikrobiyolojik inceleme yapmak klinik uygulamamıza katkı sağlamamaktadır. Ampisilin-tetrasiklin tedavisine postoperatif enfeksiyon bulguları olan hastalarda ampirik olarak başlanmalıdır

Anahtar Kelimeler: Üreteral stent, Kolonizasyon, İdrar analizi, Stent kültürü

\section{Introduction}

Ureteral double-J (DJ) stents are widely used in the treatment of ureteral obstruction and to prevent complications after endourological surgery. It is also a foreign body that is an ideal surface for bacterial adhesion and colonization with the formation of biofilms (1). Biofilm formation on DJ stents plays a major role in stent-related urinary tract infections (UTIs). Bacterial colonization occurs in 28\% to $90 \%$, and UTI is seen in 7\%-34\% of DJ stent-inserted patients. Stent-related infections are rare and mostly asymptomatic, although it may lead to severe pyelonephritis and sepsis that may result in death $(2,3)$. Ureteral stents may also cause stent-related symptoms, such as hematuria, pain, dysuria, urgency, frequency, and sense of incomplete emptying $(4,5)$. These symptoms are also seen in UTI. It is a challenging situation for the urologist to discern these two clinical scenarios. So that, the urologist tends to remove ureteral stents after obtaining sterile urine or with antibiotic suppression, however, determination of bacterial colonization with urinalysis and urine culture is insufficient. Although urine analysis and urine culture are unsatisfactory, there is currently no useful tool for the prediction of catheter-induced infection.

In the present study, we investigated the presence of bacterial colonization and its importance in terms of clinical symptoms and value/effectiveness of urine tests in predicting the results of stent cultures.

\section{Materials and Methods}

In this single-arm prospective study, we analyzed data of 65 consecutive patients in whom we placed $26 \mathrm{~cm}, 6 \mathrm{Fr}$ DJ stent following endoscopic ureter stone surgery between August 2014 and January 2015 in our urology department. The institutional ethics committee approved the study protocol (YUV-2015-312) and all patients enrolled in this study gave written informed consent.

Polyurethane DJ stent was inserted in all patients. Patients with acute pyelonephritis and having a positive urine culture before surgery were excluded considering a higher probability of bacterial colonization. Also, patients with immune suppression or deficiency and diabetes mellitus were excluded from the study.

The DJ stents were removed only after urine cultures appeared sterile or in the case of patients that sterile urine was not observed after a period of appropriate antibiotic usage. Samples with bacterial growth of $105 \mathrm{CFU} / \mathrm{mL}$ in midstream clean-catch urine were considered UTI-positive. The DJ stents were removed under sedoanalgesia with the help of a cystoscope and forceps after administration of single-dose antibiotic prophylaxis (1 $g$ i.v. cefazolin) under aseptic conditions. The removed stent was placed in a sterile box and subjected to stent culture and antimicrobial susceptibility testing. At the postoperative period, stent dwell time urine analysis results (a significant number of leukocytes (5 per HPF), nitrite positivity and positivity of leukocyte esterase) and urine culture results just before stent removal were noted. Patients were categorized according to stent culture results; group 1 had sterile stent culture, group 2 had bacterial colonization. Also, symptoms such as fever, dysuria, and flank pain were noted at the postoperative period.

Patient data including gender, age, laterality, stent dwell time, presence of hydronephrosis, stone location, and antibiotic use before stent removal were collected. These parameters and urine analysis results were compared with DJ stent culture results.

\section{Statistical Analysis}

All analyses were performed using the SPSS version 20 for Windows (SPSS Inc., Chicago, IL, USA). The Mann-Whitney U 
test and chi-square test were used for statistical analysis. A p value of less than 0.05 was considered statistically significant.

\section{Results}

A total of 65 patients (16 females and 43 males) with the mean age of $42 \pm 6.8$ years were evaluated. 12 were in group 1 and 43 were in group 2. The groups were homogeneous for preoperative characteristics (Table 1). Stent removal was done under antibiotic suppression in $4(33.3 \%)$ patients in group 1 and 18 (34.3\%) patients in group 2.

Bacterial colonization was detected in $12(18 \%)$ of the DJ stent cultures with Enterococcus faecalis $(n=4)$, extendedspectrum beta-lactamase producer [ESBL (+) Escherichia coli $(n=4)]$, Corynebacterium urealyticum $(n=2)$, Candida $(n=1)$ and methicillin-resistant Staphylococcus aureus (MRSA) $(n=1)$ growth being reported. Among patients with colonization in urine according to antibiogram results, 4 patients were sensitive to penicillin, 4 to ampicillin, 3 to tetracycline, 2 to imipenem, and 1 to linezolid $(n=1)$.

The rate of leukocyte esterase- and nitrite-positive patients, of those having a significant number of leukocytes, and urine culture-positive patients in the groups with and without positive urine culture was $58.5 \%, 32 \%, 49 \%$, and $7.5 \%$ vs $50 \%$, $16.6 \%, 50 \%$, and $8.5 \%$, respectively. There were no statistically significant differences between the groups $(p=>0.05)$ (Table 2).

All of these three parameters were positive in 2 cases in group 1 and 6 patients in group 2. Positive urine culture was detected in five patients; one in group 1 and four in group 2, there was no statistically significant differences in positive urine culture detection rate between the groups $(p=0.92)$.

\begin{tabular}{|c|c|c|c|c|}
\hline & & $\begin{array}{l}\text { Colonization } \\
\text { positive } \\
(n=12)\end{array}$ & $\begin{array}{l}\text { Colonization } \\
\text { negative } \\
(n=53)\end{array}$ & Sign. \\
\hline \multirow[t]{2}{*}{ Gender } & Male & $9(75 \%)$ & $40(75.4 \%)$ & \multirow[t]{2}{*}{0.973} \\
\hline & Female & $3(25 \%)$ & $13(24.6 \%)$ & \\
\hline \multirow[t]{2}{*}{ Laterality } & Right & $7(58.3 \%)$ & $27(50.9 \%)$ & \multirow[t]{2}{*}{0.643} \\
\hline & Left & $5(41.6 \%)$ & $26(49.1 \%)$ & \\
\hline \multicolumn{2}{|l|}{ Age (year) } & $39.0(15.4)$ & $43.5(13.1)$ & 0.303 \\
\hline \multicolumn{2}{|c|}{ Stent duration (day) } & $62.5(44.3)$ & $64.3(51.9)$ & 0.194 \\
\hline \multirow{3}{*}{$\begin{array}{l}\text { Stone } \\
\text { localization }\end{array}$} & Distal & 3 & 22 & \multirow{3}{*}{0.117} \\
\hline & Middle & 8 & 16 & \\
\hline & Proximal & 1 & 15 & \\
\hline \multicolumn{2}{|c|}{$\begin{array}{l}\text { Hydronephrosis before } \\
\text { Double-J insertion }\end{array}$} & $6(50 \%)$ & $30(56.6 \%)$ & 0.628 \\
\hline \multicolumn{2}{|c|}{ Antibiotic usage } & $4(33.3 \%)$ & $18(34.3 \%)$ & 0.967 \\
\hline
\end{tabular}

The mean time interval between insertion and removal of the stents was 62.5 (44.3) and 64.3 (51.9) days in group 1 and group 2 , respectively $(p=0.194)$. Interestingly, none of the study patients applied to our hospital with active infection following stent removal.

\section{Discussion}

The present study demonstrates that sterile urinalysis cannot rule out bacterial stent colonization. In contrast to the literature, the stent-dwell time was similar in stent culture-positive and -negative patients. Stent colonization was reported only in 12 (18.4\%) patients and, interestingly, none of these patients had any clinically significant infection after stent removal.

Bacterial colonization in DJ stents is a challenging condition for endourologists because of complications such as UTI and encrustation. In their study evaluating 93 ureteral stents from 71 patients, Riedl et al. (6) reported that bacterial colonization rate of urine cultures was $100 \%$ in permanently stented patients and $69.3 \%$ in temporarily stented patients. Our rate $(5 / 65)$ is lower than the previous ones which can be a result of the relatively shorter stent-dwell time.

In their study evaluating 237 patients, Farsi et al. (7) reported that $67 \%$ of the stents were colonized with microorganisms; the rate was 100\% for polyurethane DJ stents (3). Although we used polyurethan DJ stents, we had a lower rate of stent colonization (18\%) In another study evaluating 57 stents, Paick et al. (3) reported that the bacterial colonization rate was $0 \%$ in the first two weeks of stent placement, but later, this rate increased to $44 \%$ for (3). It is impossible to compare our first two weeks' data with their results, however, our overall colonization rates are comparable with their results. One of the possible causes of our lower rates might be antibiotic therapy before stent removal to obtain sterile urine. Paick et al. (3) also emphasized that shortterm antibiotic usage avoids the colonization on stents (3).

In the literature, identification of bacterial colonization on DJ stents with conventional culture techniques have been criticized

Table 2. Findings of urine analyses of colonized and noncolonized stents

\begin{tabular}{|l|l|l|l|}
\hline & \multicolumn{3}{l|}{$\begin{array}{l}\text { Ureteral Double-J stent } \\
\text { colonization }\end{array}$} \\
\hline Urine test & $\begin{array}{l}\text { Positive } \\
\mathrm{n}=12(18 \%)\end{array}$ & $\begin{array}{l}\text { Negative } \\
\mathrm{n}=53(82 \%)\end{array}$ & Sign. \\
\hline Nitrite positivity & $2(16.6 \%)$ & $17(32 \%)$ & 0.268 \\
\hline Leukocyte esterase positivity & $6(50 \%)$ & $31(58.5 \%)$ & 0.592 \\
\hline $\begin{array}{l}\text { Significant leucocyte } \\
\text { precense }\end{array}$ & $6(50 \%)$ & $26(49 \%)$ & 0.953 \\
\hline All of them positive & $2(16.6 \%)$ & $6(11.3 \%)$ & 0.611 \\
\hline Urine culture positive & $1(8.3 \%)$ & $4(7.5 \%)$ & 0.927 \\
\hline
\end{tabular}


$(1,7)$. Paick et al. (3) reported that microorganisms embedded in biofilms were not accurately detected with conventional diagnostic tools. Sonication was performed to displace adherent microorganisms, and sonicate-fluid culture was studied. Zhang et al. (1) investigated the morphological properties of bacterial biofilm on the surface of ureteral stents with a scanning electron microscope, and they also studied pathogens and drug sensitivity of bacteria. The biofilm formation rate was $82.9 \%$, and bacterial colonies were observed on the surface of the ureteral stents on the $7^{\text {th }}$ day (1). Our lower rates can be related to the usage of conventional culture techniques for the identification of bacteria.

Up to now, prolonged stent indwell time has been related to increases in bacterial colonization rate $(3,7,8,9,10,11,12)$. Kehinde et al. (9) investigated the factors predisposing to UTIs after DJ stent insertion and they showed that increased stent retention, sex, and systemic diseases (diabetes and chronic renal failure) enhanced bacterial colonization. Ozgur et al. (12) reported that the bacterial colonization rate increased 10 times when the indwell time was more than 6 weeks. In the literature, many studies reported that there is a significant increase in detecting positive DJ cultures results rates following a prolongation of the time from insertion to removing of DJ stent, however, in our study, we did not find any correlation between the rate of positive stent culture results and stent dwelling duration.

This can be explained that we usually removed the stents four weeks after insertion. That is a long time for bacterial colonization. A study published by Indu demonstrated that the formation of the primary biofilm starts immediately after the stent insertion, and the bacterial colonization starts seven days after insertion (13).

Stent placement causes lower urinary tract symptoms and microscopic hematuria and urinalysis findings similar to UTI. Pooli et al. (14) reported that positive urinalysis findings were poorly correlated with positive urine culture in patients with indwelling ureteral stents. Rahman et al. (15) compared the rate of positive urine culture and bacterial stent colonization just before stent removal. Bacterial colonization rate was much higher (45\%) than positive urine cultures (21\%), showing that urine culture was less sensitive than stent culture in the diagnosis of stent colonization. In our study, also there was no correlation between urine culture and urinalysis results and stent colonization.

It has been reported that gram-negative bacteria, especially Escherichia coli was the most commonly identified pathogens in stent culture and the rate of positive urine culture was only 20.1\% (16). In our study, Enterococcus faecalis and Escherichia coli were the most commonly identified uropathogens in stent culture. It was observed that preoperative treatment with ampicillin and tetracycline would be sufficient for all patients with positive urine culture results except for patients who had MRSA and ESBL+ E.coli colonization in urine culture. None of the study patients applied to our hospital with active infection following stent removal.

During stent removal, biofilm layer can be disrupted and spread into the urine resulting in uncomplicated UTI, even urosepsis. In their study including 209 children who underwent cross trigoal ureteral reimplantation, Uvin et al. (17) reported that despite the bacterial colonization rate was very high (42.9\%), only $4.6 \%$ of patients had clinically significant UTI 6 weeks after reimplantation, which makes us think that bacterial colonization of stents has very low clinical importance.

Nevo et al. (18) reported that urine and DJ cultures were positive in $9.4 \%$ of patients and only $4.7 \%$ of them had similar pathogen in both culture. Positive urine cultures were found in 91 patients $(17.8 \%)$ and positive stent cultures were found in 104 (20.4\%). Urine and stent cultures were positive in 48 patients (9.4\%), of whom only 24 had identical bacteria in both cultures. Also, the clinical significance of bacterial colonization of a DJ stent is low, only 13 of 90 positive DJ stent culture patients had positive urine culture and only 10 of the patients had symptomatic urinary tract infection. In our study, none of the patients were treated for active UTI following stent removal. This may be explained with the fact that all DJ stents were removed after obtaining a sterile urine culture or under prophylactic antibiotic usage.

Despite its small sample size, our study presents a picture of infection and asymptomatic bacteriuria in DJ-stented patients.

\section{Conclusion}

The present study demonstrates that stent culture does not give enough information to change our clinical practice and it also increases our workload. Urinalysis and urine culture are not efficient tests for predicting catheter culture results. We can extract DJ stents without any additional microbiological examination. Ampicillin-tetracycline treatment should be started empirically in patients with postoperative symptomatic infection findings and, finally, stent-indwell time should not be longer than four weeks.

\section{Ethics}

Ethics Committee Approval: The institutional ethics committee approved the study protocol (YUV-2015-312).

Informed Consent: All patients enrolled in this study gave written informed consent.

Peer-review: Externally peer-reviewed.

\section{Authorship Contributions}

Concept: A.Ş.,Y.T., Ç.A.Ş., T.T., Design: A.Ş., A.Ç., F.T., A.G., Data Collection or Processing: A.Ş., K.E., A.G., F.T., Analysis or 
Interpretation: T.T., Y.T., Ç.A.Ş., Literature Search: A.Ş., Y.T., A.Ç., Ç.A.Ş., Writing: K.E., F.T.,T.T., A.Ş.,Y.T.

Conflict of Interest: No conflict of interest was declared by the authors.

Financial Disclosure: The authors declare that they have no relevant financial.

\section{References}

1. Zhang JM, Liu J, Wang K, Zhang X, Zhao T, Luo HM. Observations of Bacterial Biofilm on Ureteral Stent and Studies on the Distribution of Pathogenic Bacteria and Drug Resistance. Urol Int 2018;13:1-7.

2. Lifshitz DA, Winkler HZ, Gross M, Sulkes J, Baniel J, Livne PM. Predictive value of urinary cultures in assessment of microbial colonization of ureteral stents. J Endourol 1999;13:735-738.

3. Paick SH, Park HK, Oh SJ, Kim HH. Characteristics of bacterial colonization and urinary tract infection after indwelling of double-J ureteral stent. Urology 2003;62:214-217.

4. Tanidir $Y$, Mangir N, Sahan A, Sulukaya M. Turkish version of the Ureteral Stent Symptoms Questionnaire: linguistic and psychometric validation. World Journal of Urology 2017;35:1149-1154.

5. Cubuk A, Yanaral F, Ozgor F, Savun M, Ozdemir H, Erbin A, Yuksel B, Sarilar 0. Comparison of $4.8 \mathrm{Fr}$ and $6 \mathrm{Fr}$ ureteral stents on stent related symptoms following ureterorenoscopy: A prospective randomized controlled trial. Kaohsiung J Med Sci 2018;34:695-699.

6. Riedl CR, Plas E, Hubner WA, Zimmerl H, Ulrich W, Pfluger H. Bacterial colonization of ureteral stents. Eur Urol. 1999;36:53-59.

7. Farsi HM, Mosli $\mathrm{HA}, \mathrm{Al}-$ Zemaity MF, Bahnassy $\mathrm{AA}$, Alvarez M. Bacteriuria and colonization of double-pigtail ureteral stents: long-term experience with 237 patients. J Endourol 1995;9:469-72.
8. Joshi R, Singh DR, Sharma S. Lower urinary tract infection and bacterial colonization in patient with double J ureteral stent. J Nepal Health Res Counc 2011;9:165-168.

9. Kehinde EO, Rotimi VO, Al-Awadi KA, Abdul-Halim H, Boland F, Al-Hunayan A, Pazhoor A. Factors predisposing to urinary tract infection after J ureteral stent insertion. J Urol 2002;167:1334-1337.

10. Klis R, Korczak-Kozakiewicz E, Denys A, Sosnowski M, Rozanski W. Relationship between urinary tract infection and self-retaining Double- $J$ catheter colonization. J Endourol 2009;23:1015-1019.

11. Lojanapiwat B. Colonization of internal ureteral stent and bacteriuria. World J Urol 2006;24:681-683.

12. Ozgur BC, Ekici M, Yuceturk CN, Bayrak 0. Bacterial colonization of double J stents and bacteriuria frequency. Kaohsiung J Med Sci 2013;29:658-661.

13. Indu KN, Lakshminarayana G, Anil M, Rajesh R, George K, Ginil K, Georgy M, Nair B, Sudhindran S, Appu T, Unni VN, Sanjeevan KV. Is early removal of prophylactic ureteric stents beneficial in live donor renal transplantation? Indian J Nephrol 2012;22:275-279.

14. Pooli A, Cook G, Isharwal S, Desai V, LaGrange C. Urinalysis findings are not predictive of positive urine culture in patients with indwelling stents. Can J Urol 2016;23:8446-8450.

15. Rahman MA, Alam MM, Shahjamal S, Islam MR, Haque ME. Predictive value of urine cultures in evaluation of bacterial colonization of ureteral stents. Mymensingh Med J 2012;21:300-305.

16. Aydin HR, Irkilata L, Aydin M, Gorgun S, Demirel HC, Adanur S, Keles M, Atilla A, Atilla MK. Incidence of bacterial colonisation after indwelling of double-J ureteral stent. Arch Ital Urol Androl 2016;87:291-294.

17. Uvin $P$, Van Baelen A, Verhaegen J, Bogaert G. Ureteral stents do not cause bacterial infections in children after ureteral reimplantation. Urology 2011;78:154-158.

18. Nevo A, Mano R, Schreter E, Lifshitz DA. Clinical Implications of Stent Culture in Patients with Indwelling Ureteral Stents Prior to Ureteroscopy. J Urol 2017;198:116-121. 